\title{
14. AN AUTHIGENIC GYPSUM, PYRITE, AND GLAUCONITE ASSOCIATION IN A MIOCENE DEEP SEA BIOGENIC OOZE FROM THE FALKLAND PLATEAU, SOUTHWEST ATLANTIC OCEAN ${ }^{1}$
}

\author{
Jay P. Muza and Sherwood W. Wise, Jr., Department of Geology, Florida State University, \\ Tallahassee, Florida
}

\begin{abstract}
Authigenic gypsum, pyrite, and glauconite are disseminated throughout an unusually long ( $346 \mathrm{~m})$ Miocene section of mixed biogenic carbonate and diatomaceous ooze drilled on the Falkland Plateau at DSDP Site 329 (water depth, $1519 \mathrm{~m}$ ). The present organic carbon content of the sediment is low, ranging between 0.1 and $0.7 \%$. Gypsum occurs as euhedral single or twinned crystals of selenite up to $5 \mathrm{~mm}$ in diameter, sometimes in the form of gypsum rosettes. These crystals are intact and unabraded, comprising up to $4 \%$ of the washed sample. The authigenic nature of the gypsum is demonstrated by the presence of diatoms and radiolarians embedded within the gypsum crystals.

The gypsum co-occurs with pyrite and glauconite in these samples. The pyrite occurs as framboids, foraminiferal infillings, rods, and granular sheetlike masses composed of pyrite octahedra. The glauconite occurs as foraminiferal infillings and as free grains. The gypsum and pyrite were identified by energy-dispersive X-ray analysis and scanning electron micrographs. Some of the gypsum has grown on pyrite, indicating that it precipitated after the pyrite, perhaps in response to a change in $\mathrm{pH}$ conditions. The formation of the mineral suite can be explained by current models of in situ sulfide and sulfate precipitation coincident with diagenesis and oxidation of much of the original organic carbon.
\end{abstract}

\section{INTRODUCTION}

Reports of authigenic gypsum in bathyal or abyssal marine sediments have been few, and hypotheses regarding its origin are necessarily somewhat speculative. Nonevaporative marine gypsum, sometimes in association with authigenic pyrite, has to date been sampled nearly exclusively in short piston-core sections. We present here a description of an association of authigenic gypsum, pyrite, and glauconite in an unusually long (346 m) deep sea section of mixed biogenic carbonate and diatomaceous ooze drilled on the Falkland Plateau at Deep Sea Drilling Project Site 329 (Fig. 1). The existence of such an extensive section provides ample, readily available material for any future studies concerned with particular aspects (for example, the geochemistry) of such deposits. Our interest in the authigenic association addressed in this paper is primarily in the rather unusual occurrence of the gypsum.

\section{PREVIOUS STUDIES}

Previous studies of the occurrence of gypsum in marine sediments have been summarized by Siesser and Rogers (1976) and by Briskin and Schreiber (1978). Siesser and Rogers (1976) describe an association of authigenic pyrite and authigenic gypsum along with sandsized glauconite and quartz from silty clays recovered at depths of 632 and 900 meters along the Southwest African continental slope. Calcareous nannofossils date the sediments as late Miocene-early Pliocene in age. The pyrite occurred as granular masses, "worm" tubes, foraminiferal infillings, and framboids. Gypsum, as euhe-

${ }^{1}$ Ludwig, W. J., Krasheninnikov, v. A., et al., Init. Repts. DSDP, 71: Washington (U.S. Govt. Printing Office). dral single or twinned crystals of selenite, sometimes partially or completely enclosed the "worm" tubes and foraminiferal infillings of pyrite. In this region today, the upwelling of cold, nutrient-enriched waters supports high plankton productivity, creating a belt of anoxic sediments deposited within an oxygen-minimum zone. Siesser and Rogers (1976) believe that such conditions prevailed along the continental slope during a late Miocene to early Pliocene regression. Drawing on the work of Berner $(1964,1969,1970)$ and Goldhaber and Kaplan (1974), Siesser and Rogers (1976) speculated that anaerobic bacteria thrived in this environment, reducing $\mathrm{SO}_{4}$ dissolved in seawater and initiating the formation of $\mathrm{H}_{2} \mathrm{~S}$. The $\mathrm{H}_{2} \mathrm{~S}$ would have reacted immediately with iron present in the sediment to form FeS. The transformation of this monosulfide to disulfide would require the addition of elemental sulfur. As the strongly reducing, low-pH environment became saturated with calcium obtained by the dissolution of calcareous microfossils, gypsum would be precipitated once the product of the concentrations of dissolved calcium and $\mathrm{SO}_{4}$ exceeded the gypsum solubility product. The gypsum, then, like the pyrite, formed in situ within the sediment.

The South African occurrences described by Siesser and Rogers (1976) were reminiscent of those described by Robert and Chamley (1974) among Pleistocene deep sea sapropels of the Mediterranean. Gypsum and pyrite were present in three samples out of eight taken between 790 and 3710 meters. The organic content of the sapropels was lower in the samples containing gypsum and pyrite than in those containing pyrite alone $(5 \%$ versus $10 \%$ ). In addition, in samples containing both gypsum and pyrite, the calcite was less dissolved, the clays were less degraded, diatom frustules were less numerous, and trace elements were less abundant. Most importantly, 


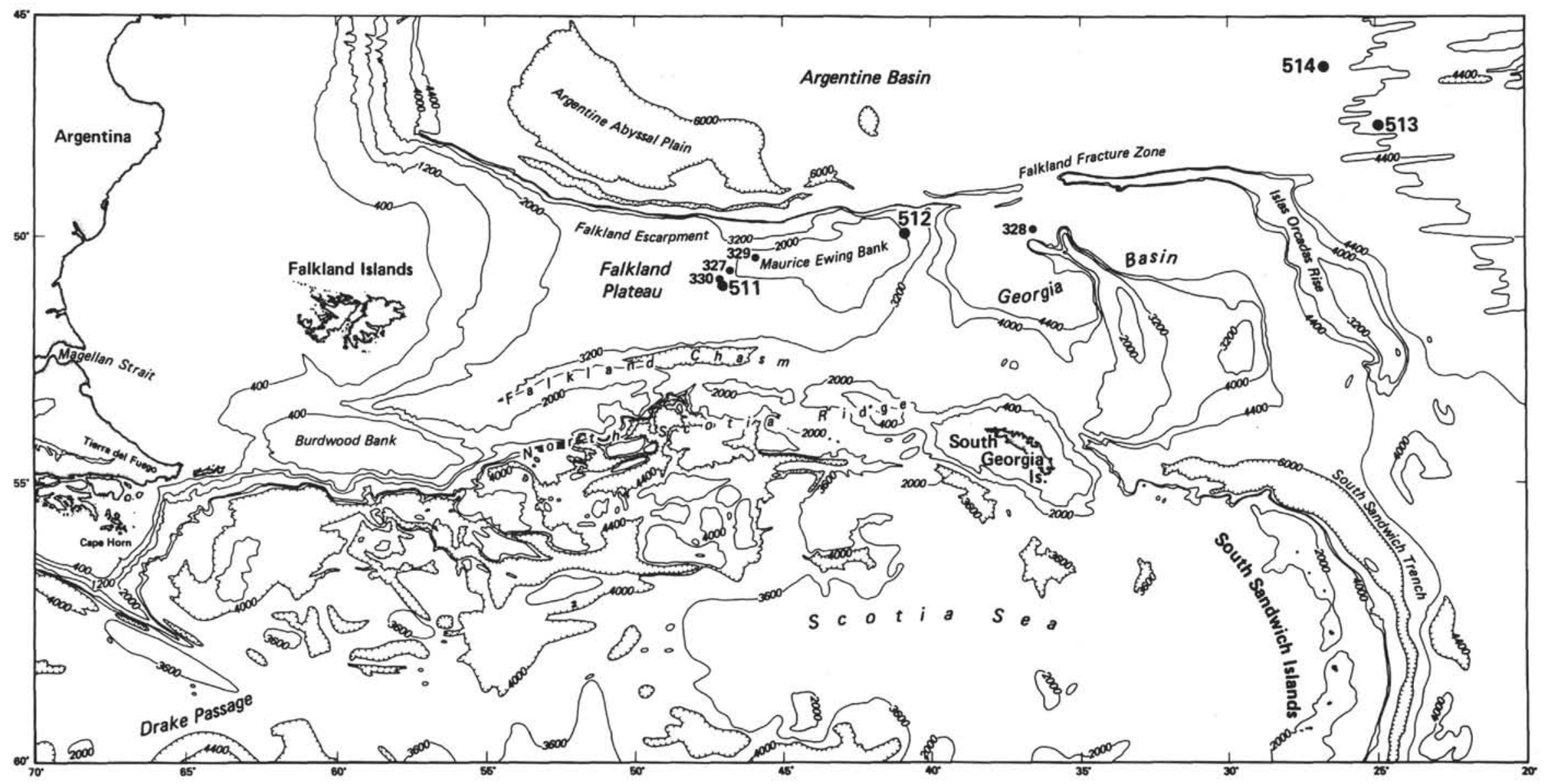

Figure 1. Location map, DSDP Site 329. 
the environment was a little less anoxic, and the slightly higher oxidation state favored the formation of sulfate. According to Robert and Chamley (1974), the presence of aerobic as well as anaerobic bacteria may have been a factor.

In a paper devoted primarily to the occurrence of pyrite in calcareous oozes drilled at DSDP Site 251, Southwest Indian Ocean, Criddle (1974) made note of gypsum laths and rosettes which he found to be common in his samples. Criddle also suggested a link between the occurrence of the pyrite and the gypsum. Noting the absence of detrital minerals in the coccolith ooze, he suggested that the necessary iron for pyrite formation was derived largely from the dissolution of calcareous nannofossils in the ooze. These nannoplankton also provided, according to Criddle, the organic substrate for the bacteria responsible for sulfate reduction and hence the source of sulfur. Gypsum in turn was formed by the reaction of sulfate ions introduced during pyrite formation with biogenic carbonate of the sediment.

Briskin and Schreiber (1978) tabulated three modes of gypsum occurrence in deep sea sediments, citing examples primarily from piston cores they examined. They tabulated examples in the following categories: (A) reworked clastic (nonauthigenic), (B) tabular authigenic, and $(C)$ prismatic or acicular authigenic. They also referred to two examples reported from glacial clays of the Weddell Sea by Bannister and Hey (1936). The authigenic nature of these latter gypsums has been questioned (Arrhenius, 1963), however, because there was a lag of several years between the recovery of the samples and the eventual identification of the gypsum. Briskin and Schreiber further cite numerous examples of gypsum precipitation which took place after core recovery, upon desiccation of the interstitial solutions, particularly during core storage.

In the typical carbonate deep sea oozes studied by Briskin and Schreiber (1978), the gypsum had precipitated in the absence of pyrite. Unlike the sediments described by Siesser and Rogers (1976) and by Robert and Chamley (1974), their sediments were neither highly anoxic nor rich in sulfur and detrital minerals. Briskin and Schreiber, therefore, considered various other sources for $\mathrm{S}$ and $\mathrm{SO}_{4}=$ and speculated on the possible role of sulfide-oxidizing bacteria and on chemical reactions which would allow a high sulfate retention to be achieved. They performed detailed stratigraphic and quantitative studies of a piston core from the Rio Grande Rise (water depth, $4021 \mathrm{~m}$ ) where tabular gypsum crystals were found to have grown around fragmented or whole planktonic foraminiferal tests. They derived a complicated model by which climatic shifts (cold phase) would have stimulated productivity and increased organic deposition on the seafloor. During warm phases, the influx of oxygen-rich, undersaturated Antarctic Bottom Water over the basin floor would actively dissolve the foraminiferal ooze, supplying the necessary $\mathrm{Ca}^{++}$for gypsum precipitation at the sediment/water interface (as opposed to precipitation in situ within the sediment).

\section{METHODS}

The authigenic minerals described here were recovered from washed residues of core samples which had been prepared for stable isotopic studies of foraminifers (Muza et al., this volume). One sample from every second core of the Miocene section at DSDP Site 329 had been soaked for two hours in a Calgon solution to aid disaggregation; afterward each sample was washed in tap water on a $63 \mu \mathrm{m}$ screen. Estimates of the amount of authigenics in the washed residues were made visually under a dissecting microscope. Mineral specimens were handpicked from the residue for examination in a Cambridge S4-10 scanning electron microscope equipped with a backscatter electron detector. A few of the picked gypsum specimens were also soaked in a $10 \%$ $\mathrm{HCl}$ solution to clean the surface of microfossils. All SEM micrographs shown are backscattered images. The SEM elemental analyses were performed on the specimens using an attached Tracor-Northern energy-dispersive X-ray system (EDS).

\section{FALKLAND PLATEAU OCCURRENCES}

\section{Host Lithology}

The 346-meter-thick section in which the authigenic minerals occur was drilled at an intermediate water depth of 1519 meters at the apex of the Maurice Ewing Bank of the Falkland Plateau. The lithology consists of diatom ooze and nannofossil ooze mixed and interlayered in various proportions. This unit has also been penetrated by one additional drill hole, DSDP Site 512 (Fig. 1; see also Site 512, this volume) and by numerous piston cores taken in the area (Ciesielski and Wise, 1977; Wise et al., 1978). The organic carbon content within the section ranges from 0.1 to $0.7 \%$ (Cameron, 1977 , table 2). The minimum average sediment accumulation rates calculated by Barker, Dalziel, et al. (1977) were about $35 \mathrm{~m} / \mathrm{m} . y$. , a very high average.

Barker, Dalziel, et al. (1977) divided the section into two units, Unit $1 \mathrm{~b}(4.5-225 \mathrm{~m}$, Cores 1-21) and Unit 1c (225-350 m, Cores 22-26), which they describe in some detail. Unit $1 \mathrm{~b}$ consists of 220 meters of mixed calcareous nannofossil and diatom ooze with varying proportions of clastic detritus and biogenic components. Colors are predominantly shades of green, gray, and olive; the lighter shades are commonly associated with a higher calcareous component. Diatoms and calcareous nannofossils form the bulk of the biogenic fraction. Radiolarians (up to $15 \%$ ), silicoflagellates $(15 \%)$, sponge spicules $(5 \%)$, and foraminifers $(5 \%)$ are locally significant but decrease down-section to trace amounts. The sandand silt-sized clastic fraction, mainly quartz and subordinate feldspar grains, occurs only in trace amounts below Core 4. Green phyllosilicates and volcanic glass also occur in trace amounts below Core 4. Pyrite was reported in the lower half of the unit as dark streaks and disseminations through the sediment. Pyrite was also seen to replace some siliceous fossils.

Unit 1c, 125 meters thick, is of a similar lithology with the addition of chalk beds within the sequence. As described by Barker, Dalziel, et al. (1977), diatoms and calcareous nannofossils are again the dominant biogenic components, with radiolarians up to $3 \%$; other fossils occur only in trace amounts. Clay is generally present only in trace amounts as are zeolite, green phyllosili- 
cates, volcanic glass, and quartz. Traces of pyrite occur throughout the unit, locally forming dark streaks and partially replacing some siliceous fossils. Burrow mottling is extensive in the chalky layers.

\section{Authigenic Minerals}

The occurrence of gypsum, pyrite, and glauconite in the washed residues, as determined by visual observation, is tabulated in Table 1 . Some of the pyrite occurred as irregular, sheetlike, granular masses of crystal octahedrons (Plate 1, Figs. 1-4), much like those described by Criddle (1974) and Siesser and Rogers (1976). EDS analysis of these specimens (Table 2, A) shows the expected high iron and sulphur readings, with minor calcium and silicon that is possibly from included or adhering microfossils. The phosphorus and some of the calcium is a contaminant from the Calgon solution (to be explained later). The iron content of the pyrite, however, is over twice that which would be expected from $\mathrm{FeS}_{2}$. This suggests the possibility that some other iron sulfide mineral species could be present in addition to pyrite (W. Parker, pers. comm. 1982). A more massive, grainlike aggregate of pyrite (Plate 2, Fig. 1) on close examination turned out to be composed of scattered pyrite framboids within a matrix of fine pyrite crystals (Plate 2, Fig. 2). The elemental analysis for this occurrence (Table 2, B) is similar to that of the sheetlike masses. Pyrite also occurred as long solid or hollow rods (Plate 2, Fig. 3; Plate 3, Fig. 1) which resemble the "worm tubes" described by Siesser and Rogers (1976). In many

Table 1. Gypsum, pyrite and glauconite in $63-\mu \mathrm{m}$ washed samples, Hole 329.

\begin{tabular}{|c|c|c|c|}
\hline $\begin{array}{l}\text { Core/Section } \\
\text { (interval in cm) }\end{array}$ & Gypsum & Pyrite & Glauconite \\
\hline $2-5,130-132$ & None & None & Trace \\
\hline $4-5,130-132$ & $\begin{array}{l}2 \% \text {, up to } 3 \mathrm{~mm} \text { dia., } \\
\text { single, twinned, and } \\
\text { rosette translucent } \\
\text { crystals }\end{array}$ & None & Trace \\
\hline $6-5,130-132$ & $\begin{array}{l}3 \% \text {, up to } 3 \mathrm{~mm} \text { dia., } \\
\text { single, twinned } \\
\text { translucent crystals }\end{array}$ & $\begin{array}{l}\text { Trace, infillings or re- } \\
\text { placement in dia- } \\
\text { toms, radiolarians }\end{array}$ & Trace \\
\hline $8-5,130-132$ & None & None & Trace \\
\hline $10-6,130-132$ & $\begin{array}{l}1 \% \text {, up to } 1 \mathrm{~mm} \text { dia., } \\
\text { single translucent } \\
\text { crystals }\end{array}$ & $\begin{array}{l}\text { Trace, infillings or re- } \\
\text { placement in dia- } \\
\text { toms, radiolarians }\end{array}$ & Trace \\
\hline $14-5,123-125$ & $\begin{array}{l}3 \% \text {, up to } 5 \mathrm{~mm} \text { dia., } \\
\text { singular, twinned } \\
\text { translucent crystals }\end{array}$ & $\begin{array}{l}1 \% \text {, infillings or re- } \\
\text { placement in dia- } \\
\text { toms, radiolarians, } \\
\text { and foraminifers; } \\
\text { granular masses }\end{array}$ & $1 \%$ \\
\hline $16-4,130-132$ & None & $\begin{array}{l}\text { Trace, infillings or re- } \\
\text { placement in diatoms }\end{array}$ & Trace \\
\hline $18-5,130-132$ & $\begin{array}{l}3 \% \text {, up to } 5 \mathrm{~mm} \text { dia., } \\
\text { rosettes, single, and } \\
\text { twinned translucent } \\
\text { crystals }\end{array}$ & $\begin{array}{l}1 \% \text {, infillings or re- } \\
\text { placement in benthic } \\
\text { foraminifers, dia- } \\
\text { toms; sheetlike gran- } \\
\text { ular masses }\end{array}$ & Trace \\
\hline $20-5,130-132$ & $\begin{array}{l}\text { Trace, up to } 1 \mathrm{~mm} \text { dia., } \\
\text { single translucent } \\
\text { crystals }\end{array}$ & $\begin{array}{l}1 \% \text {, infillings or partial } \\
\text { replacement in dia- } \\
\text { toms and radiolarians }\end{array}$ & Trace \\
\hline $22-4,120-122$ & $\begin{array}{l}2 \% \text {, up to } 2 \mathrm{~mm} \text { dia., } \\
\text { single, translucent } \\
\text { crystals }\end{array}$ & $\begin{array}{l}1 \% \text {, infillings or re- } \\
\text { placement in dia- } \\
\text { toms and radiolarians }\end{array}$ & $2 \%$ \\
\hline $24, \mathrm{CC}$ & $\begin{array}{l}4 \% \text {, up to } 3 \mathrm{~mm} \text { dia., } \\
\text { rosettes and single } \\
\text { translucent crystals }\end{array}$ & $\begin{array}{l}1 \% \text {, infillings or partial } \\
\text { replacement in } \\
\text { diatoms and ra- } \\
\text { diolarians }\end{array}$ & Trace \\
\hline $26-3,130-132$ & None & None & Trace \\
\hline
\end{tabular}

Table 2. EDS analysis of gypsum, pyrite, and glauconite associations, Hole 329.

\begin{tabular}{|c|c|c|c|}
\hline & Area & & \\
\hline $\begin{array}{c}\text { Peak } \\
\text { energy }\end{array}$ & $\begin{array}{c}\text { Gaussian } \\
\text { Curve }\end{array}$ & Element & $\begin{array}{l}\text { Spectral } \\
\text { line }\end{array}$ \\
\hline
\end{tabular}

A. Sheetlike pyrite octahedra

$\begin{array}{lrll}1.481 & 869 & \mathrm{Al} & \mathrm{KA} \\ 1.743 & 2774 & \mathrm{Si} & \mathrm{KA} \\ 2.009 & 496 & \mathrm{Zr} & \mathrm{LA} \\ 2.315 & 23997 & \mathrm{~S} & \mathrm{KA} \\ 3.320 & 529 & \mathrm{~K} & \mathrm{KA} \\ 3.699 & 5046 & \mathrm{Ca} & \mathrm{KA} \\ 4.028 & 580 & \mathrm{Ca} & \mathrm{KB} \\ 6.407 & 27734 & \mathrm{Fe} & \mathrm{KA} \\ 7.061 & 4048 & \mathrm{Fe} & \mathrm{KB}\end{array}$

B. Pyrite framboids

$\begin{array}{rrrr}1.472 & 272 & \mathrm{Al} & \mathrm{KA} \\ 1.743 & 2199 & \mathrm{Si} & \mathrm{KA} \\ 2.313 & 15734 & \mathrm{~S} & \mathrm{KA} \\ 3.304 & 167 & \mathrm{~K} & \mathrm{KA} \\ 3.695 & 799 & \mathrm{Ca} & \mathrm{KA} \\ 6.405 & 13671 & \mathrm{Fe} & \mathrm{KA} \\ 7.061 & 1801 & \mathrm{Fe} & \mathrm{KB}\end{array}$

C. Pyritized foraminiferal test

$\begin{array}{rrrr}1.475 & 799 & \mathrm{Al} & \mathrm{KA} \\ 1.746 & 4829 & \mathrm{Si} & \mathrm{KA} \\ 2.313 & 7760 & \mathrm{~S} & \mathrm{KA} \\ 3.323 & 1055 & \mathrm{~K} & \mathrm{KA} \\ 3.697 & 1796 & \mathrm{Ca} & \mathrm{KA} \\ 6.407 & 26239 & \mathrm{Fe} & \mathrm{KA} \\ 7.065 & 3742 & \mathrm{Fe} & \mathrm{KB}\end{array}$

D. Rod-shaped specimen

$\begin{array}{lrll}1.466 & 3267 & \text { Al } & \text { KA } \\ 1.746 & 61215 & \text { Si } & \text { KA } \\ 2.317 & 427 & \text { S } & \text { KA } \\ 3.323 & 4069 & \mathrm{~K} & \text { KA } \\ 3.687 & 1765 & \mathrm{Ca} & \text { KA } \\ 6.409 & 1295 & \text { Fe } & \text { KA }\end{array}$

E. Calgon coating on gypsum crystal

$\begin{array}{lrll}1.231 & 141 & \mathrm{Mg} & \mathrm{KA} \\ 1.484 & 3448 & \mathrm{Al} & \mathrm{KA} \\ 1.732 & 686 & \mathrm{Si} & \mathrm{KA} \\ 2.015 & 26513 & \mathrm{P} & \mathrm{KA} \\ 2.325 & 3242 & \mathrm{P} & \mathrm{KB} \\ 3.305 & 657 & \mathrm{~K} & \mathrm{KA} \\ 3.698 & 56644 & \mathrm{Ca} & \mathrm{KA} \\ 4.026 & 7108 & \mathrm{Ca} & \mathrm{KB} \\ 6.407 & 413 & \mathrm{Fe} & \mathrm{KA}\end{array}$

F. Gypsum rosette

$\begin{array}{rrrr}1.473 & 492 & \mathrm{Al} & \mathrm{KA} \\ 1.743 & 672 & \mathrm{Si} & \mathrm{KA} \\ 2.313 & 39370 & \mathrm{~S} & \mathrm{KA} \\ 3.697 & 43726 & \mathrm{Ca} & \mathrm{KA} \\ 4.026 & 5200 & \mathrm{Ca} & \mathrm{KB}\end{array}$

G. Glauconite grains

$\begin{array}{lrll}1.240 & 1312 & \mathrm{Mg} & \mathrm{KA} \\ 1.463 & 1729 & \mathrm{Al} & \mathrm{KA} \\ 1.742 & 82176 & \mathrm{Si} & \mathrm{KA} \\ 3.319 & 9518 & \mathrm{~K} & \mathrm{KA} \\ 3.678 & 3005 & \mathrm{Ca} & \mathrm{KA} \\ 4.025 & 457 & \mathrm{Ca} & \mathrm{KB} \\ 4.516 & 1379 & \mathrm{Ti} & \mathrm{KA} \\ 6.405 & 31985 & \mathrm{Fe} & \mathrm{KA} \\ 7.058 & 4209 & \mathrm{Fe} & \mathrm{KB}\end{array}$

H. Fish tooth

\begin{tabular}{rrrr}
1.485 & 866 & $\mathrm{Al}$ & $\mathrm{KA}$ \\
2.015 & 14483 & $\mathrm{P}$ & $\mathrm{KA}$ \\
2.339 & 267 & $\mathrm{P}$ & $\mathrm{KB}$ \\
3.698 & 38196 & $\mathrm{Ca}$ & $\mathrm{KA}$ \\
4.028 & 4445 & $\mathrm{Ca}$ & $\mathrm{KB}$ \\
\hline
\end{tabular}


instances it was possible to determine that these rods were formed by the infilling of benthic foraminiferal tests. Through a sequence of specimens, one could see that as the infilling proceeded the carbonate tests dissolved, leaving the pyrite core which in effect "replaced"' the microfossil test. The outer surfaces of these specimens did not exhibit pyrite framboids but rather a platy structure (Plate 2, Fig. 4). Using a backscatter image detector, the surface of these specimens appeared mottled, which suggests a rather irregular mineral distribution (Plate 3, Fig. 1). This mottled surface image resulted from variations in the emission from the specimen of backscattered (primary) electrons which are a function of elemental composition. These specimens registered very high iron content in relation to sulfur (Table 2, C). One rod-shaped specimen registered a uniform rather than a mottled backscattered image (Plate 3, Fig. 2). Its X-ray signature reads low in iron but high in silicon (Table 2, D), indicating that the infilling in this case is predominantly some form of silica, possibly opal-CT.

Gypsum occurred as what appeared to be single crystals, twinned crystals, or rosettes ranging up to $5 \mathrm{~mm}$ in size. The specimens in Plate 3 , Figures 3 and 4 , were washed very little in tap water and still have centric diatoms adhering to their surface. The specimen in Plate 4 was washed a bit more thoroughly in tap water but is still covered with a fine film from the Calgon solution, which cracked upon desiccation. A number of the microfossils on the surface of this specimen are partially embedded within the gypsum itself, having been partially enveloped during crystal growth (Plate 4, Figs. 1 and 2). The actual surface of the gypsum is seen where the Calgon coating has flaked away, exposing a fibrous or prismatic crystal microstructure beneath (Plate 4, Fig. 3). An X-ray map of phosphorus and sulfur clearly distinguishes between the gypsum and the Calgon coating (Plate 4, Fig. 4). An elemental readout on the Calgon coating (Table 2, E) shows high phosphorus and calcium with minor aluminum, potassium, and silicon. Sulfur was not recorded, since no reading was obtained from the gypsum below the coating. Phosphorus, calcium, potassium, silicon, and aluminum must be considered contaminants, to some extent, therefore, in all other readings taken from specimens not treated in $\mathrm{HCl}$.

One specimen consists of two gypsum rosettes which grew on either end of a pyrite rod (Plate 5, Figs. 1-3). This specimen was cleaned in a $10 \% \mathrm{HCl}$ solution which removed the Calgon coating. Although the gypsum rosettes consist of thin unabraded blades, a few blades have been broken off (Plate 5, Fig. 2), probably during cleaning or handling. During the cleaning process, the $\mathrm{HCl}$ reacted with the gypsum to etch the crystal surface, thereby accentuating the fibrous character of the gypsum (Plate 6, Figs. 1 and 2). Also noted after etching was a radiolarian test embedded in the gypsum (Plate 6, Fig. 2). Etching removed some gypsum around this siliceous microfossil test, but did not affect the test itself. The etched gypsum surface of the cluster in Plate 5, Figure 2, provided an opportunity to get an elemental reading from the gypsum without contamination from adher- ing materials (Table 2, F). These readings were as expected, except for minor traces of silicon and calcium. The surface of the pyrite rod is rough and granular and, as in the case of the others examined, exhibits a rather uneven distribution of iron as shown by the elemental map for iron (Plate 6, Fig. 4; same specimen and magnification as in Pl. 6, Fig. 3).

Other gypsum rosettes cleaned in $\mathrm{HCl}$ are illustrated in Plate 7, Figures 1-4. Close examination reveals a centric diatom frustule around which a small cavity has been etched in the gypsum by the $\mathrm{HCl}$ (Plate 7, Fig. 4).

Glauconite occurs as infillings of foraminiferal tests and as free grains which appear as ovoid masses (Plate 8 , Figs. 3 and 4). The latter exhibit a system of large cracks, visible in the light microscope, from which a series of finer submicroscopic cracks are developed. These specimens were not cleaned in $\mathrm{HCl}$; however, the elemental analysis of the specimen in Plate 8, Figure 2 shows the expected high iron and silicon plus some manganese and titanium (Table 2, G).

Detrital grains observed in the sample consisted of small amounts of volcanic glass, rare fish teeth (Plate 8, Fig. 2; Table 2, H), and roughly textured quartz grains which yield predominantly silicon EDS readings (Plate 8, Fig. 1).

\section{DISCUSSION}

The problem of reworked and secondary gypsum in deep sea cores has been discussed in detail by Briskin and Schreiber (1978). Reworking of gypsum from older units was initially considered a possibility for the Falkland Plateau sediments because erosion along this feature during the Miocene was extensive and some reworking of older Tertiary microfossils has been noted (Ciesielski and Wise, 1977; Wise et al., 1982). Gypsum rosettes have been reported from the Mesozoic strata from the Plateau sampled at nearby DSDP Site 511 (Fig. 1; Timofeev, this volume). Briskin and Schreiber (1978), however, note that where gypsum is a product of reworking, some of the crystals should show signs of breakage or abrasion. This is not generally the case for the specimens we examined, since most of the delicate crystal margins are unabraded and intact. The breakage noted on a few of the rosette blades (for example, the small rosette, Plate 5) could be attributed to the washing and cleaning procedures. In addition, it is unlikely that the growiths of gypsum and pyrite could have survived a cycle of erosion-transportation-redeposition or that such a cycle could have yielded the quantity of gypsum we found without producing evidence of other identifiable reworked Mesozoic material, either fossil or mineral. The strongest indications that the gypsum crystals grew within the diatom nannofossil oozes, however, are the siliceous microfossil inclusions noted in the light and electron microscopes (Plate 6, Fig. 2; Plate 7, Fig. 4).

The formation of secondary gypsum after core retrieval is not uncommon in sediments having a high organic content (Briskin and Schreiber, 1978) and is another possibility that must be considered. Excellent examples of this are seen among the Upper Jurassic to Lower Cretaceous black mudstone cores taken during 
DSDP Leg 71 at Site 511 (see Site 511 site chapter, this volume). Extensive growths of gypsum crystals developed on the split surfaces of these cores within a year of their storage in a humidity-controlled, refrigerated depository. We doubt that this was the case with the Miocene material we observed because the present organic content of those oozes is quite low compared to those other examples where secondary gypsum formed. Any secondary gypsum that might have formed would have been volumetrically insignificant and undetectable. This does bring up the question of whether the gypsum rosettes reported from Hole 511 cores by Timofeev (this volume) are natural or an artifact of sample storage.

Accepting then that the material we are dealing with is authigenic, we can next speculate on the mode of origin of the gypsum-pyrite-glauconite association. High planktonic productivity is a common thread in the models proposed by most of the previous authors who have sought to explain the accumulation of an adequate amount of organic matter on the seafloor (Siesser and Rogers, 1976; Briskin and Schreiber, 1978). Heath et al. (1976) further note that the rate of accumulation of organic carbon in marine sediments is closely related to the bulk sediment accumulation rate. The sediment accumulation rate on the Falkland Plateau during the Miocene was certainly high, owing largely to high productivity among the plankton, since the bulk of the sediment there is biogenic. Heath et al. (1976) also note that there is a diagenetic reduction of organic carbon in older sediments that appears to be exponential in both reducing and oxidizing environments, with half-lives in the $15,000-55,000 \mathrm{y}$. range. They cite one example from the Santa Barbara Basin where the organic carbon content dropped from about $4 \%$ at the top of the core to about $1 \%$ at the base ( $8 \mathrm{~m}$ sub-bottom) (Heath et al., 1976, fig. 8). The organic content of the Miocene sediments on the Falkland Plateau, therefore, was probably considerably higher initially than it is at present. Thus the necessary conditions for the proliferation of anaerobic bacteria were probably met at the time of accumulation. The scenario outlined by Siesser and Rogers (1976; see Introduction to this chapter) for both pyrite and sulfate precipitation, therefore, could probably have been carried out despite the low organic content of the sediments compared to those they studied. Because of this relatively low organic content of the Falkland sediments, however, a role for aerobic bacteria in the precipitation of the pyrite, as suggested by Robert and Chamley (1974) and by Briskin and Schreiber (1978), can also be contemplated although we have no way of ascertaining this. Whether the dissolution of calcareous nannofossils released organic carbon and iron as suggested by Criddle (1974) is a hypothesis also beyond our present ability to test. It is interesting to note, however, that Heath et al. (1976) found that conventional organic carbon analyses (such as the type run on our material by Cameron, 1977) systematically understate total organic carbon values. This is because carbon locked in carbonate skeletal material is lost during a leaching phase of sample preparation prior to the carbon analysis. For this reason, more carbon may be present and available in the Miocene oozes than Cameron's analysis would indicate.

The source of calcium for gypsum formation was assured by the abundance of calcareous nannofossils in the sediment. Calcareous microfossils in any sediment pile undergo some in situ alteration through a dissolution-diffusion-reprecipitation process reviewed in detail by Wise (1976). The relative position of the carbonate compensation level in relation to Site 329 was highly important in the overall accumulation of the Miocene oozes, because the CCD controlled carbonate accumulation in this region during the Miocene. Carbonate accumulated at intermediate but not at deeper abyssal depths during the early through early late Miocene and only at shallow depths during the latest Miocene (Wise, 1981).

The sources of iron for both glauconite and pyrite are not immediately obvious. As noted in the description of the host lithology, detrital clastics and volcanic debris occur in only trace amounts below Core 329-4. Iron in the form of glauconite and sometimes iron-manganese is locally common in Falkland Plateau sediments at various levels from the Oligocene to Recent. Southwest of Site 329 , iron manganese pavements have seriously impeded piston coring of Miocene/Pliocene and older outcrops along the Plateau (Ciesielski and Wise, 1977; Wise et al., 1978), but we have yet to detect manganese in the Site 329 Miocene ooze. Whether iron or some other constituent such as organic carbon was the limiting factor in pyrite formation is not immediately clear. This is a subject for future research.

Nevertheless, the necessary ingredients for gypsum, pyrite, and glauconite formation seem to have been available during the deposition of the biogenic oozes in question. The formation of the gypsum was undoubtedly in situ during early diagenesis, since this is the only mechanism which would have allowed the calcium concentration to build up to sufficient levels for gypsum precipitation. This being the case, no special bottom current or climatic conditions need be invoked to explain the gypsum formation. The most important factor seems to have been the high productivity of the surface waters which supplied carbonate, organic matter, and biogenic silica, which were deposited rapidly enough to trap a sufficient amount of organic carbon in the sediment to fuel the reactions. Heath et al. (1976) found that in recently deposited open-ocean sediments there is a high correlation between total sediment accumulation rates and total organic carbon content. Also important at Site 329 was the stability of the high-productivity system which allowed the proper conditions to be maintained long enough to accumulate the thick sequence in which gypsum and the minerals associated with it were precipitated.

\section{ACKNOWLEDGMENTS}

We are indebted to William I. Miller, III, and Mary E. Parker for the scanning electron micrographs and the elemental analyses. Kim Riddle printed the micrographs and Ms. Parker and Rob Case helped prepare the plates and the manuscript, which was typed by Sharon Reeves. Dr. William C. Parker (FSU) critically reviewed the manu- 
script. Both he and Dr. B. Charlotte Schreiber (Lamont-Doherty Geologic Observatory) provided much helpful discussion. This research was supported by NSF grant DPP 80-20382.

\section{REFERENCES}

Arrhenius, G., 1963. Pelagic sediments. In Hill, M. N. (Ed.), The Sea (Vol. 3): London (Interscience), 655-718.

Bannister, F. A., and Hey, M. H., 1936. Report on some crystalline components of the Weddell Sea deposits. Discovery Repts., 13: 60-69.

Barker, P. F., Dalziel, I. W. D., et al., 1977. Site 329. In Barker, P., Dalziel, I. W. D., et al., Init. Repts. DSDP, 36: Washington (U.S. Govt. Printing Office), 143-206.

Berner, R. A., 1964. An idealised model of dissolved sulfate distribution in recent sediments. Geochim. Cosmochim. Acta, 28: 1497-1503. 383-384.

1969. The synthesis of framboidal pyrite. Econ. Geol., 64: 1-23.

1970. Sedimentary pyrite formation. Am. J. Sci., 268:

Briskin, M., and Schreiber, B. C., 1978. Authigenic gypsum in marine sediments. Mar. Geol., 28:37-49.

Cameron, D. H., 1977. Grain-size and carbon/carbonate analyses, Leg 36. In Barker, P. F., Dalziel, I. W. D., et al., Init. Repts. DSDP, 36: Washington (U.S. Govt. Printing Office), 1047-1050.

Ciesielski, P. F., and Wise, S. W., 1977. Geologic history of the Maurice Ewing Bank of the Falkland Plateau (Southwest Atlantic sector of the Southern Ocean) based on piston and drill cores. Mar. Geol., 25:175-207.

Criddle, A. J., 1974. A preliminary description of microcrystalline pyrite from the nannoplankton ooze at Site 251, Southwest Indian Ocean. In Davies, T. A., Luyendyk, B. P., et al., Init. Repts. $D S D P$, 26: Washington (U.S. Govt. Printing Office), 603-607.
Goldhaber, M. B., and Kaplan, I. R., 1974. The sulfur cycle. In Goldberg, E. D. (Ed.), The Sea, Vol. 5: Marine Chemistry: New York (Interscience), 569-655.

Heath, G. R., Moore, T. C., and Dauphin, J. P., 1976. Organic carbon in deep-sea sediments. In Andersen, N. R., and Malahoff, A. (Eds.), The Fate of Fossil Fuel $\mathrm{CO}_{2}$ in the Oceans: New York (Plenum), pp. 605-625.

Robert, C., and Chamley, H., 1974. Gypse et sapropels profonds de Méditerranée orientale. C. R. Acad. Sci. Paris, Ser. D, 278: 843-846.

Siesser, W. G., and Rogers, J., 1976. Authigenic pyrite and gypsum in South West African continental slope sediments. Sedimentology, 23:567-577.

Wise, S. W., 1976. Chalk formation: Early diagenesis. In Andersen, N. R., and Malahoff, A. (Eds.), The Fate of Fossil Fuel $\mathrm{CO}_{2}$ in the Oceans: New York (Plenum), pp. 717-739.

, 1981. Deep sea drilling in the Antarctic: Focus on late Miocene glaciation and applications of smear-slide biostratigraphy. In Warme, J. E., Douglas, R. G., and Winterer, E. L. (Eds.), The Deep Sea Drilling Project: A decade of progress. Soc. Econ. Paleontol. Mineral., Spec. Publ., 32:471-487.

Wise, S. W., Ciesielski, P. F., MacKenzie, D. T., Wind, F. H., Busen, K. E., Gombos, A. M., Haq, B. U., Lohmann, G. P., Tjalsma, R. C., Harris, W. K., Hedlund, R. W., Beju, D. N., Jones, D. L., Plafker, G., and Sliter, W. V., 1982. Paleontologic and paleoenvironmental synthesis for the Southwest Atlantic Ocean basin, based on Jurassic to Holocene faunas and floras from the Falkland Plateau. In Craddock, C. (Ed.), Antarctic Geoscience: Madison, Wisconsin (Univ. Wisconsin Press), pp. 155-163.

Wise, S. W., Jones, S. C., Ciesielski, P. F., Georgi, D. T., Wooddroffe, D. S., and Jacobs, S. S., 1978. Islas Orcadas Cruise 16. Antarct. J. U.S., 13(4):92-94. 

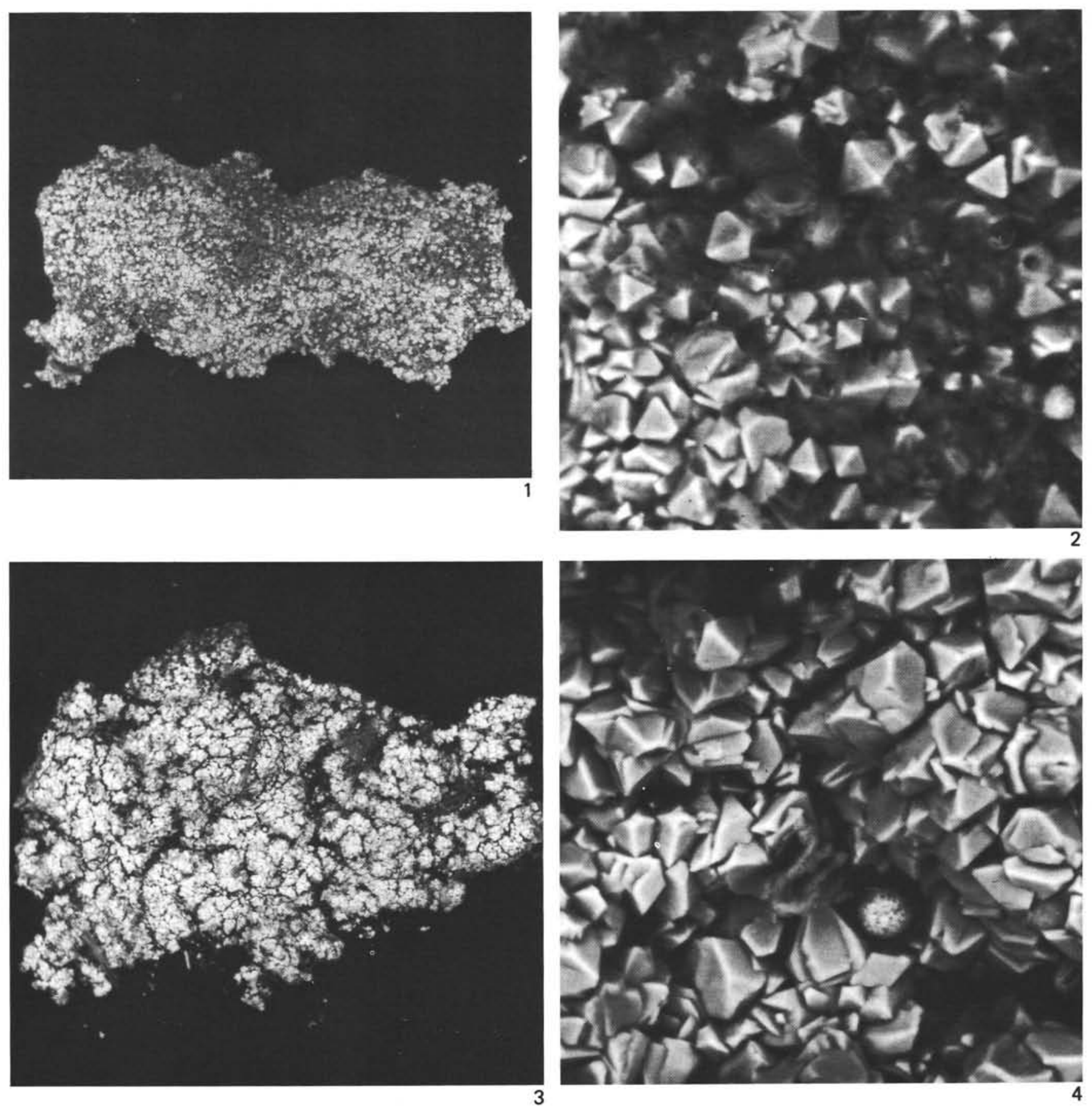

Plate 1. Sample 329-18-5, $130 \mathrm{~cm}$. 1-4. Irregular sheetlike masses of octahedral pyrite crystals. An elemental analysis for the specimen in Figures 1 and 2 is given in Table 2, A. (1) $\times 140$, (2) detail of 1 showing octahedral crystals, $\times 1400,(3) \times 160$, (4) detail of 3; note small pyrite framboid (lower right center) amongst larger octahedrons, $\times 1500$. 

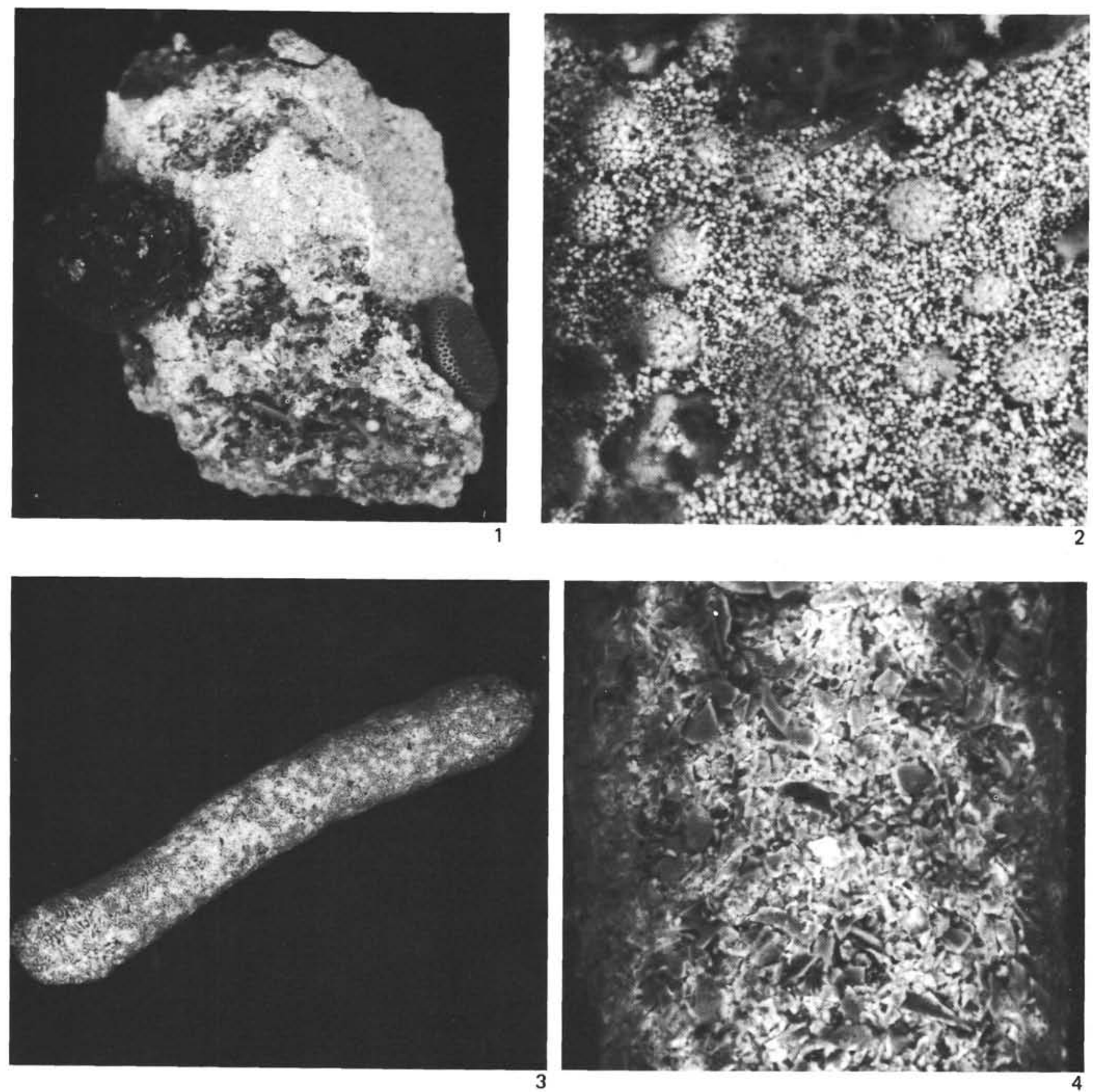

Plate 2. Sample $329-18-5,130 \mathrm{~cm}$. 1. Massive grainlike aggregate of pyrite, $\times 260$. 2. Detail of 1 , showing scattered pyrite framboids within a fine matrix of pyrite crystals. An elemental analysis for this sample is given in Table 2, B; $\times 1500$. 3. Pyritized benthic foraminiferal test, $\times 90$. 4. Detail of 3 , illustrating platy surface microstructure and absence of visible framboids, $\times 500$. 

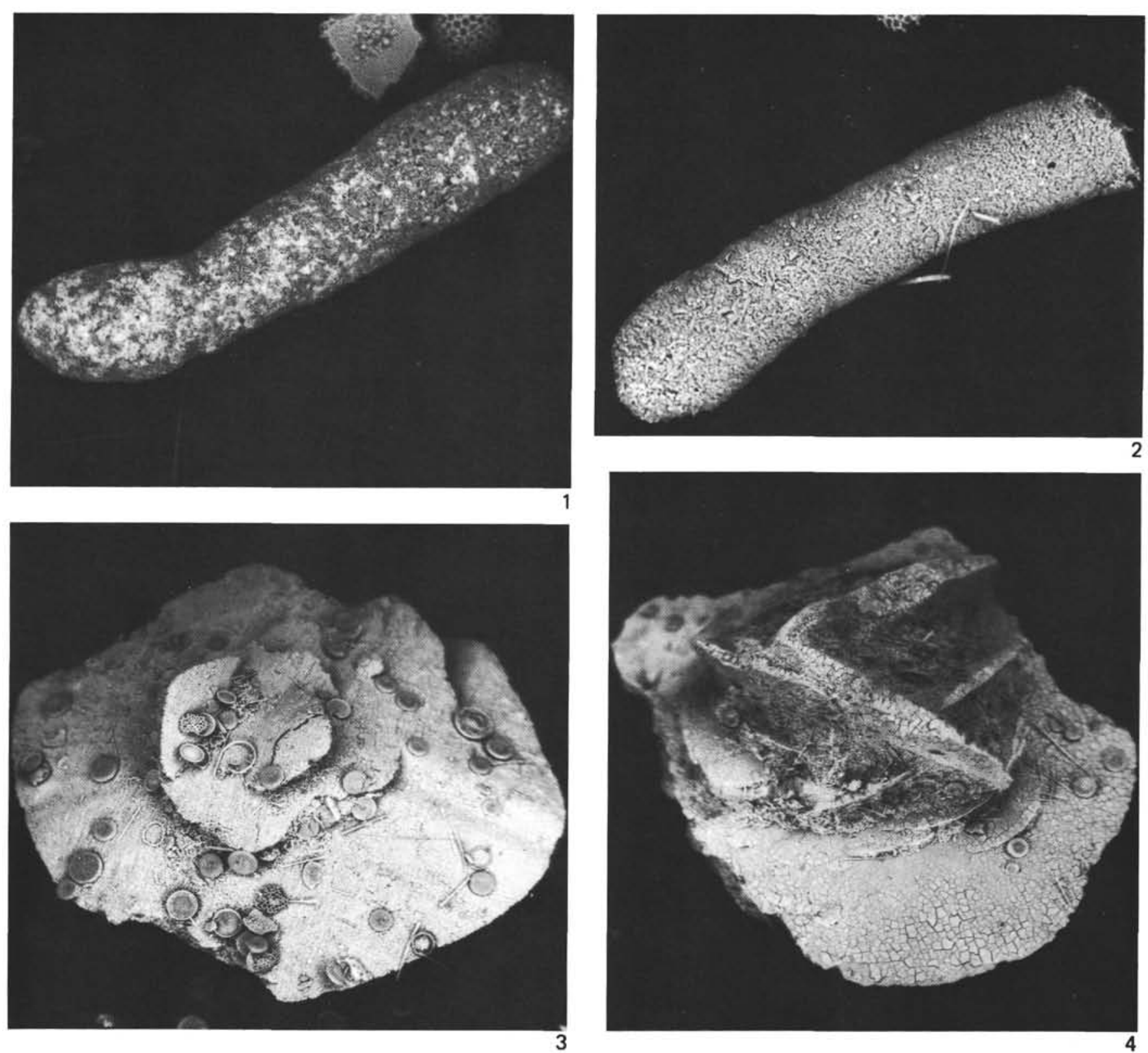

Plate 3. 1. Pyritized foraminiferal test(?) or "worm tube". Backscatter image detector reveals a mottled surface appearance that suggests irregular distribution of iron in the specimen; elemental analysis shows a high Fe content (Table 2, C), $\times 130$, Sample 329-18-5, 130 cm. 2. Rod-shaped specimen with a uniform rather than mottled backscattered image; X-ray analysis shows the composition to be mostly silica (Table 2, D); $\times 120$, Sample 329-14-5, $123 \mathrm{~cm}$. 3-4. Twinned gypsum rosettes; specimens poorly cleaned with adhering diatom frustules; Sample 329-14-5, 123 cm, (3) $\times 40$, (4) $\times 30$. 

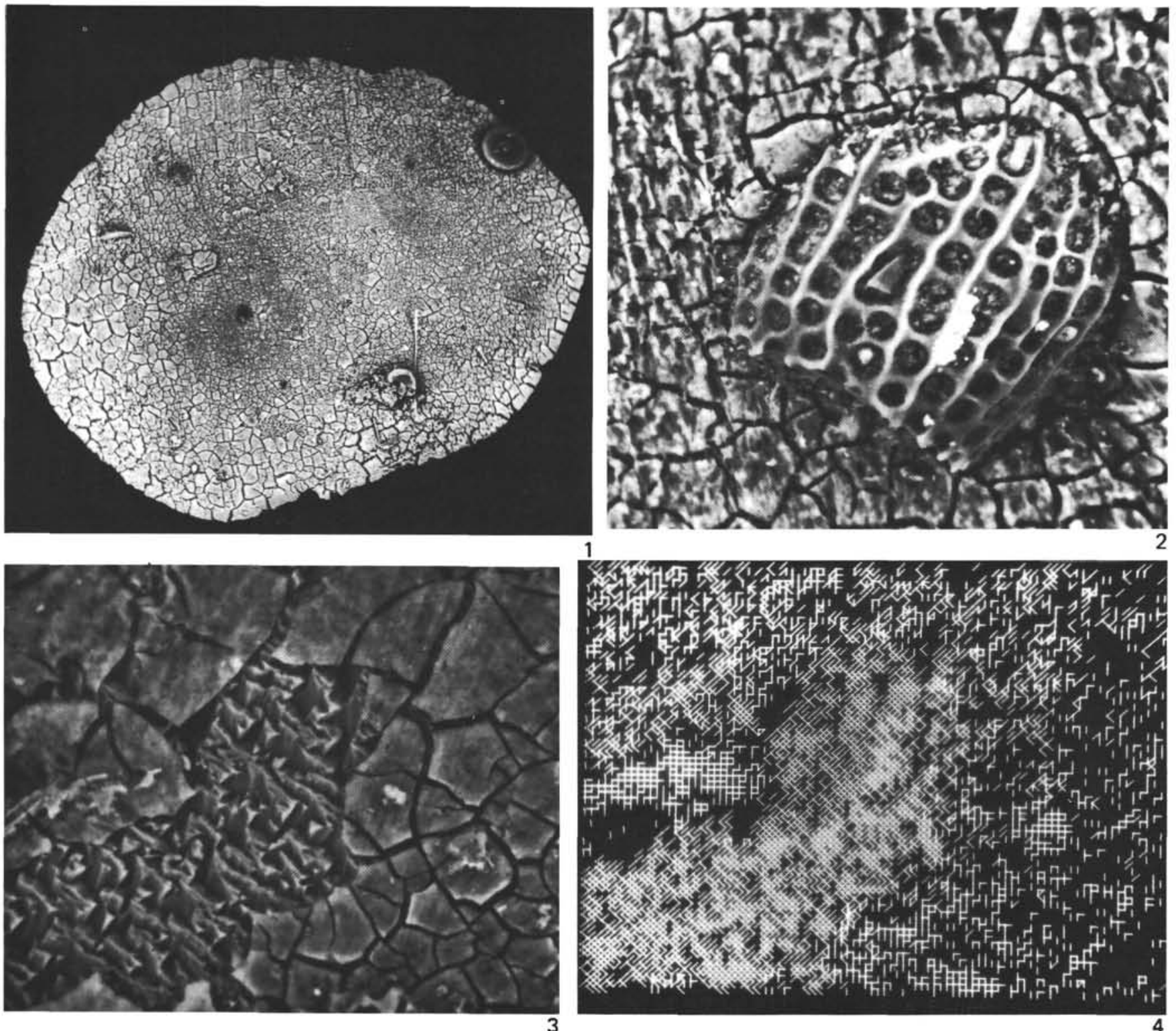

Plate 4. 1. Single(?) gypsum crystal, surface covered with a thin film of Calgon residue cracked from dessication. Some diatoms were enveloped during crystal growth (arrow), and frustules are embedded within the crystal, $\times 60$, Sample $329-10-6,130 \mathrm{~cm} .2$. Radiolarian test partially enveloped in the gypsum during crystal growth, $\times 580$, Sample 329-4-5, $129 \mathrm{~cm}$. 3. Detail of 1 , showing fibrous nature of crystal and prism terminations(?) on the surface; crystal surface exposed where Calgon film has flaked off; $\times 600$. 4 . X-ray map of 3 for phosphorus and sulfur (more solid pattern, center and lower left) clearly distinguishes between the gypsum and the Calgon coating. An elemental analysis of the Calgon coating shows high phosphorus and calcium (Table $2, \mathrm{E}) ; \times 600$. 

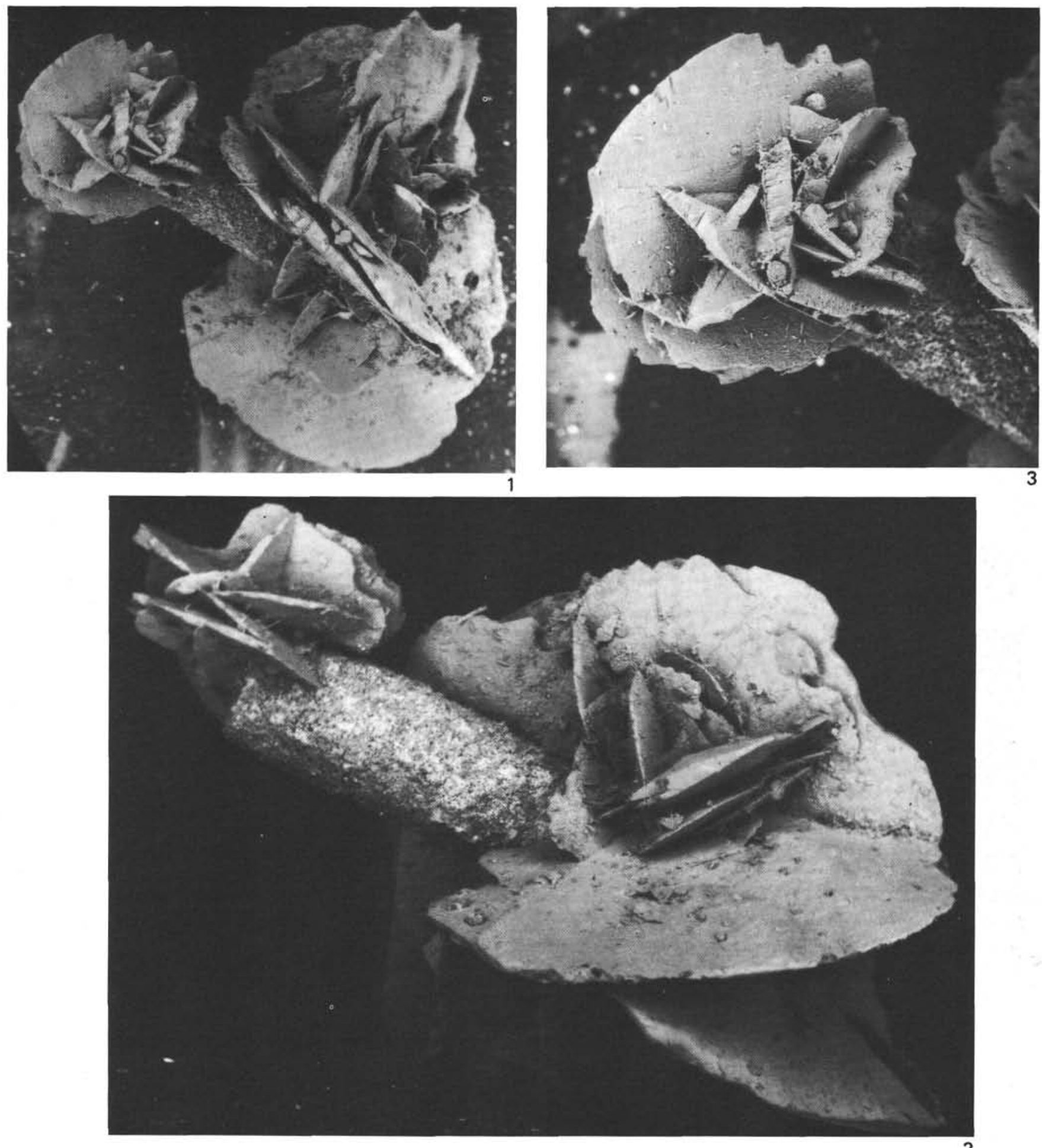

2

Plate 5. Sample 329-18-5, $130 \mathrm{~cm}$. 1-3. Gypsum rosettes growing at either end of a pyrite rod; the gypsum must have precipitated after the pyrite. Specimen was washed in $10 \% \mathrm{HCl}$ to remove adhering calcareous matter and microfossils, (1) $\times 16,(2) \times 30$; (3) detail of 1 showing the small rosette, $\times 40$. The Calgon coating was also removed by the treatment. Edges of the rosette crystals are unabraded but one crystal blade in the center has been broken off, probably during specimen preparation or handling; an elemental analysis of a blade of this rosette is given in Table 2, F. 

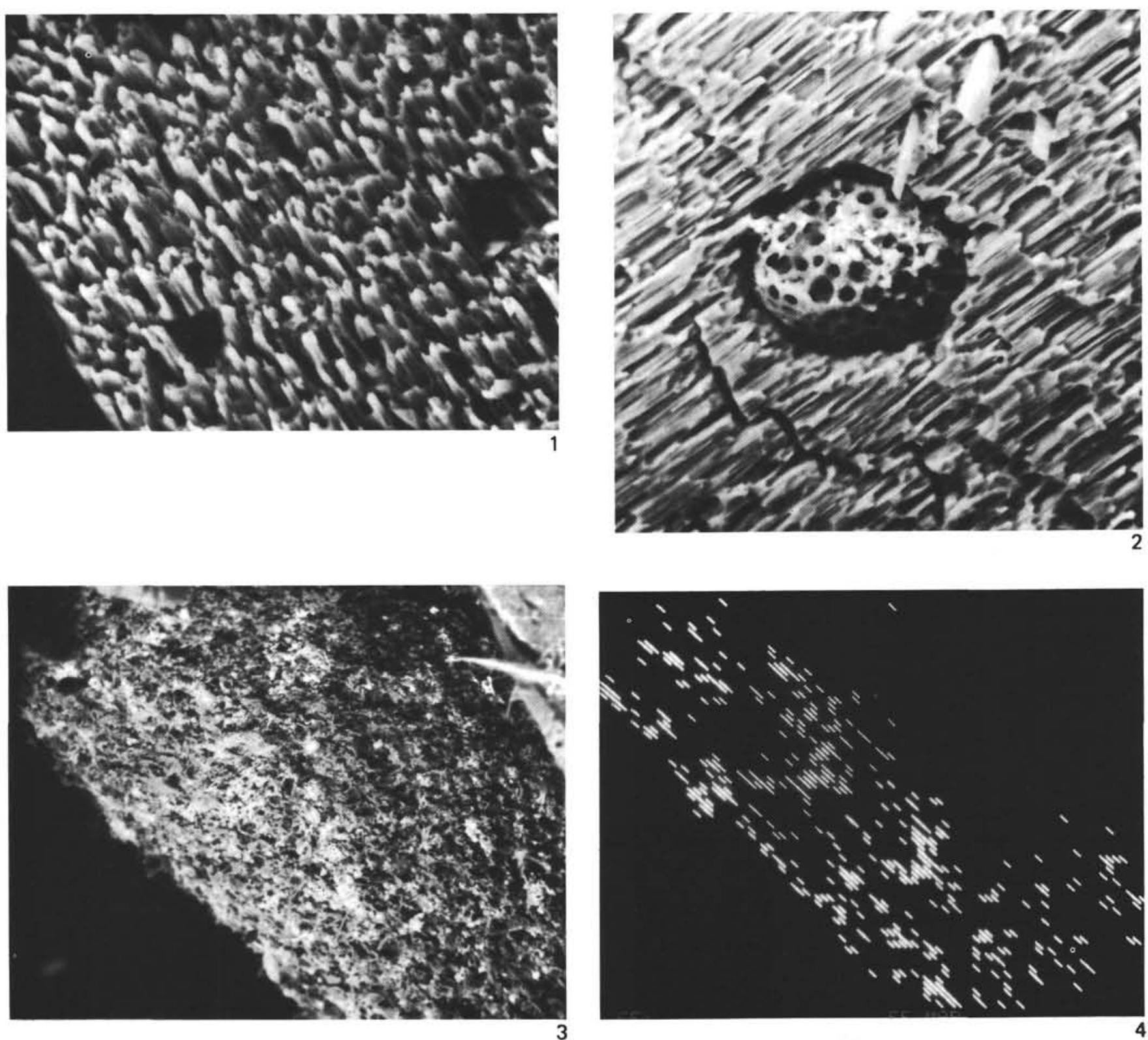

Plate 6. Sample $329-18-5,130 \mathrm{~cm}$. 1-2. Surface ultrastructure of the small gypsum rosette in Plate 5, (1) reaction with the $10 \% \mathrm{HCl}$ solution etched the crystal surface, thereby accentuating the fibrous character of the gypsum; $\times 1100,(2)$ radiolarian test originally embedded in the gypsum, now partially excavated by the acid etch; $\times 700$, (3) surface detail of pyrite rod of specimen figured in Plate $5, \times 130$. 4 . X-ray elemental map for $\mathrm{Fe}$ of rod in 3 shows an uneven distribution of iron in the specimen (same view as 3 ), $\times 130$. 

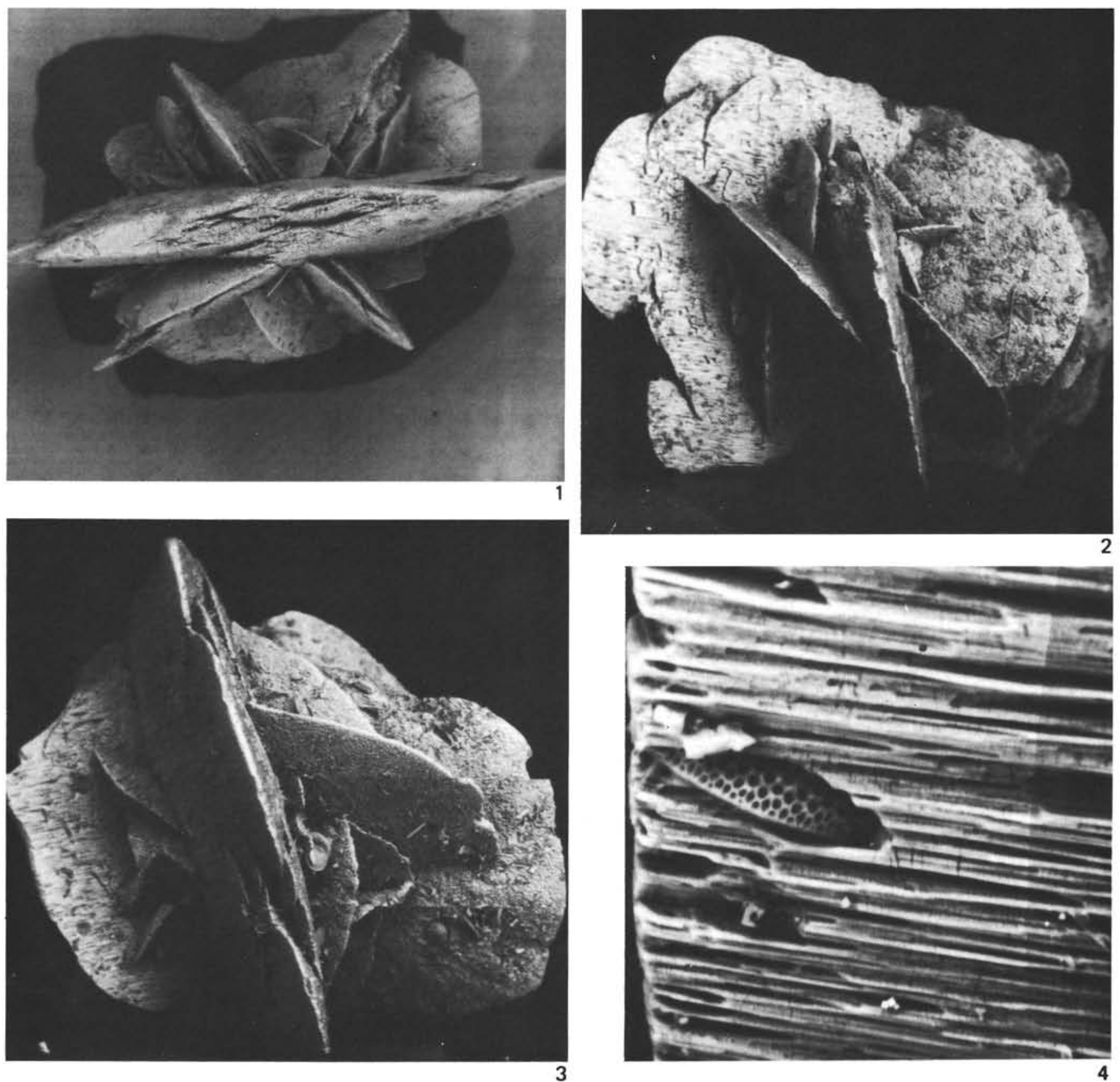

Plate 7. Sample 329-18-5, $130 \mathrm{~cm}$. 1-4. Gypsum rosettes, cleaned in $10 \% \mathrm{HCl}$, (1) black background silhouetting specimen is rendered by finger nail polish used to adhere the specimen to the SEM stub; $\times 30,(2) \times 30,(3) \times 40$, (4) detail of etched crystal surface showing prismatic fibrous nature of crystal structure and a diatom frustule partially etched from the crystal; $\times 500$. 

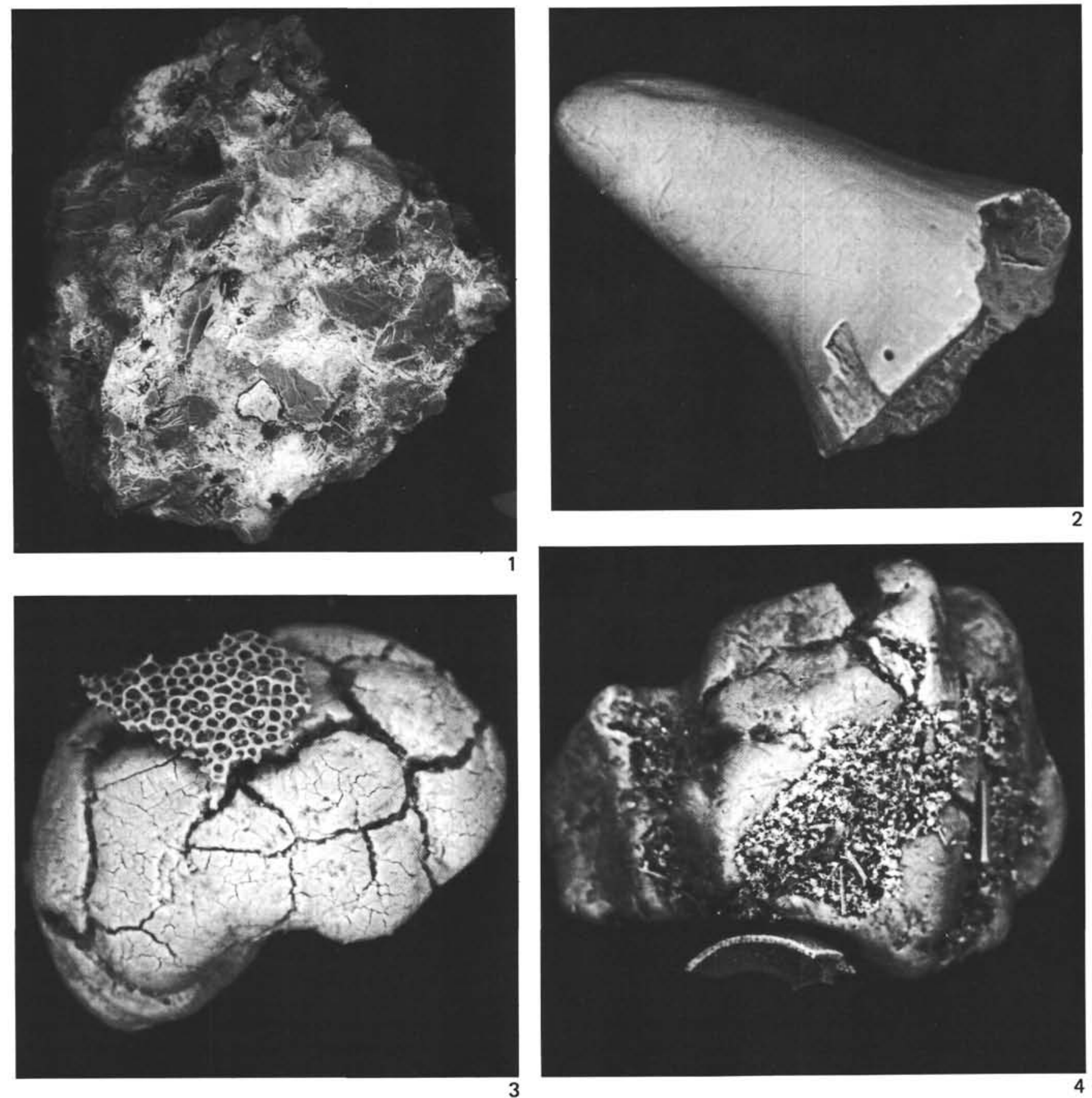

Plate 8. 1. Rough-textured quartz grain (volcanic?), $\times 100$, Sample $329-4-5,130 \mathrm{~cm}$. 2. Fish tooth, $\times 460$, Sample $329-4-5,130 \mathrm{~cm}$. $3-4$. Glauconite grains which occur as infillings in foraminiferal tests and as free grains; note cracked ovoid structure, $\times 300$, (3) Sample 329-4-5, 130 cm, (4) Sample 326-10-6, $130 \mathrm{~cm}$; elemental analysis in Table 2, G. 